\title{
Designing of long wavelength cut thin film filter for temperature reduction of concentrator photovoltaic
}

\author{
Nawwar Ahmad ${ }^{1}$, Keisuke Hatakeyama ${ }^{1}$, Yasuyuki Ota ${ }^{1}$ and Kensuke Nishioka ${ }^{1, a}$ \\ ${ }^{1}$ Faculty of Engineering, University of Miyazaki, 1-1, Gakuen Kibanadai Nishi, Miyazaki 889-2192, Japan.
}

\begin{abstract}
This paper presents a comparison of three-dimensional simulation for concentrator photovoltaic module using two types of multi-junction solar cell. Each had its own range of spectral response and based on that range a thin film filter was developed for each case to reflect the unused spectral of the solar spectrum and allowed the desired spectrum to reach the solar cell. The thin film was deposited on a secondary optical element that was used to homogenize the irradiance distribution on the solar cell. A thermal simulation was conducted to compare the resulted decrease in cell temperature due to the use of the thin film for each case.
\end{abstract}

\section{Introduction}

Concentrator photovoltaic (CPV) system is considered one of the most promising technologies in the field of solar energy which have received an increasing attention in R\&D in recent years [1]. A CPV system utilizes the inexpensive optical elements, such as Fresnel lenses to concentrate sunlight into a small-size III-V multi-junction solar cell [2]. Multi-junction solar cells are influenced by their operating temperature. Decreasing solar cell temperature can have great impact on the open circuit voltage, maximum power point and efficiency of the multi-junction cell. In this paper we propose a Fresnel lens optical concentration system with concentration ratio of 1322 times.

The optical systems concentrate solar irradiance on two types of solar cells. Each has its own spectral response range, the first cell is $\mathrm{InGaP} / \mathrm{InGaAs} / \mathrm{Ge}$ triple junction solar cell with high spectral response in the range from $400 \mathrm{~nm}$ to $1700 \mathrm{~nm} \mathrm{[3],} \mathrm{and} \mathrm{the} \mathrm{other} \mathrm{is}$ $\mathrm{InGaP} / \mathrm{GaAs} / \mathrm{InGaAs}$ triple junction solar cell with high spectral response in the range from $400 \mathrm{~nm}$ to $1100 \mathrm{~nm}$ [4]. We used thin film filter to utilize the part of solar spectrum which is beneficial to the solar cell while reflecting the rest of the long wavelength spectrum which will result in reduce of the cell temperature.

\section{Optical model}

Ray-trace calculation was conducted for the optical system using commercial optical simulation software ZEMAX. The optical system consists of typical flat Fresnel lens as primary optical element with dimensions of $200 \mathrm{~mm} \times 200 \mathrm{~mm}$ as incident ray area (focal length $=$ $420 \mathrm{~mm}$ ), and secondary optical element (homogenizer).
Figure 1 shows the schematic diagram of the CPV optical structure. The homogenizer $(14 \mathrm{~mm} \times 14 \mathrm{~mm}$ as entry aperture area, $5.5 \mathrm{~mm} \times 5.5 \mathrm{~mm}$ as exit aperture area, and $40 \mathrm{~mm}$ in height) was set at the focal point of the Fresnel lens. The used thin film was deposited at the entry aperture of the homogenizer, and the resulted intensity distribution of the concentrated light was analysed. The distance between Fresnel lens and solar cell was $460 \mathrm{~mm}$. the geometrical concentration ratio for this system was 1,322 times.

The spectral irradiance using ray trace simulation was AM1.5 (total power: $900 \mathrm{~W} / \mathrm{m}^{2}$ ). Ray trace was carried out in the wave length from 300 to $2500 \mathrm{~nm}$ to show the effect of the thin film on the overall performance of the system.

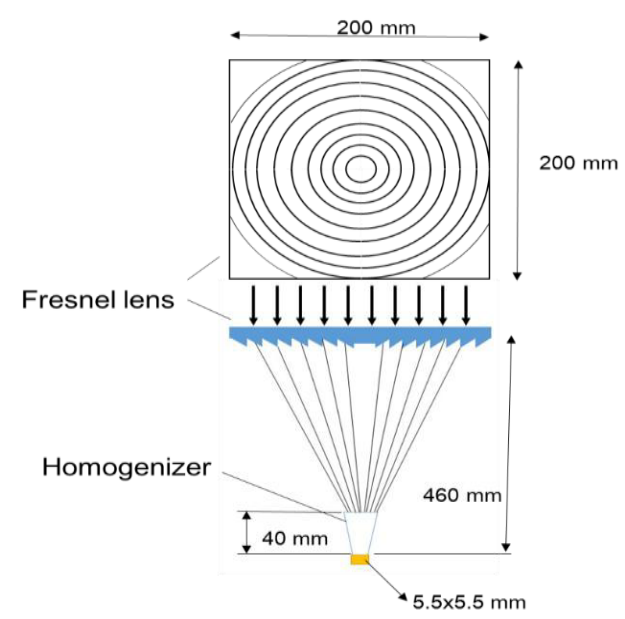

Figure 1. Schematic Diagram of the CPV optical structure.

\footnotetext{
anishioka@cc.miyazaki-u.ac.jp
} 


\section{Thin film Design}

For designing the thin film there is different traditional optimization method wildly accepted and used, nevertheless most used optimization technique for thin film are greatly affected by the initial structure of the used film, which may cause a local convergence, Tikhonravov et al. [5,6] has developed a powerful optimization method called Needle optimization technique. The two materials in the filter are $\mathrm{H}$ which has the high refractive index (in our case $\mathrm{TiO}_{2}$ ), while $\mathrm{L}$ has the low refractive index material (in our case $\mathrm{SiO}_{2}$ ).

Using needle optimizing and TFcalc (commercial thin film design software), we developed two filters; the first filter was used for the $\mathrm{InGaP} / \mathrm{InGaAs} / \mathrm{Ge}$ triple junction solar cell concentrator module and it only allowed the spectrum in the range from 400 to $1700 \mathrm{~nm}$ to be transmitted onto the solar cell while reflecting the rest of the long wavelength spectrum. The resulted structure consisted of 65 layers and had a thickness of $3490.4 \mathrm{~nm}$. It's expressed as follow:

S $731.37 \mathrm{~L} 4.15 \mathrm{H} \quad 36.04 \mathrm{~L} 5.42 \mathrm{H} 22.65 \mathrm{~L} \quad 7.46 \mathrm{H} \quad 17.42 \mathrm{~L}$ $9.99 \mathrm{H} 12.16 \mathrm{~L} 16.17 \mathrm{H} \quad 11.12 \mathrm{~L} \quad 111.53 \mathrm{H} \quad 14.33 \mathrm{~L} 20.22 \mathrm{H}$ 20.39L $10.89 \mathrm{H} \quad 42.16 \mathrm{~L} \quad 6.5 \mathrm{H} \quad 254.28 \mathrm{~L} \quad 6.41 \mathrm{H} \quad 39.05 \mathrm{~L}$ $9.16 \mathrm{H} \quad 18.17 \mathrm{~L} \quad 20.3 \mathrm{H} \quad 13.99 \mathrm{~L} \quad 130.37 \mathrm{H} \quad 15.79 \mathrm{~L} \quad 25.23 \mathrm{H}$ $\begin{array}{lllllll}42.99 \mathrm{~L} & 10.24 \mathrm{H} & 250.9 \mathrm{~L} & 8.42 \mathrm{H} & 44.82 \mathrm{~L} & 23.89 \mathrm{H} & 15.7 \mathrm{~L}\end{array}$ $137.42 \mathrm{H} \quad 15.15 \mathrm{~L} 23.01 \mathrm{H} \quad 43.1 \mathrm{~L} \quad 8.07 \mathrm{H} \quad 260.08 \mathrm{~L} \quad 8.52 \mathrm{H}$ $\begin{array}{lllllll}41.91 \mathrm{~L} & 24.87 \mathrm{H} & 14.18 \mathrm{~L} & 130.73 \mathrm{H} & 14 \mathrm{~L} & 16.6 \mathrm{H} & 15.96 \mathrm{~L}\end{array}$ $7.22 \mathrm{H} 40 \mathrm{~L} \quad 4.06 \mathrm{H} 274.14 \mathrm{~L} 5.24 \mathrm{H} 32.43 \mathrm{~L} 7.28 \mathrm{H} 14.9 \mathrm{~L}$ $19.55 \mathrm{H} 6.57 \mathrm{~L} 135.53 \mathrm{H} 14.98 \mathrm{~L} 14.43 \mathrm{H} 25.97 \mathrm{~L} 11.64 \mathrm{H}$ 93.2L A,

where $\mathrm{S}$ is the substrate in this case it's BK7 and A stands for air.

As for the thin film used for the InGaP/GaAs/InGaAs triple junction solar cell it transmitted the spectrum in the range from 400 to 1100 $\mathrm{nm}$ and reflected the rest of the long wavelength spectrum. It's expressed as:

S $6.61 \mathrm{H} 38.65 \mathrm{~L} 12.67 \mathrm{H} 22.3 \mathrm{~L} 14.71 \mathrm{H} 22.05 \mathrm{~L} 12.98 \mathrm{H}$ $\begin{array}{lllllll}29.1 \mathrm{~L} & 9.05 \mathrm{H} & 50.39 \mathrm{~L} & 2.82 \mathrm{H} & 452.84 \mathrm{~L} & 9.08 \mathrm{H} & 38.66 \mathrm{~L}\end{array}$ $25.18 \mathrm{H} \quad 12.45 \mathrm{~L} \quad 133.25 \mathrm{H} \quad 7.69 \mathrm{~L} \quad 22.55 \mathrm{H} \quad 30.71 \mathrm{~L} \quad 9.82 \mathrm{H}$ $230.37 \mathrm{~L} \quad 7.52 \mathrm{H} \quad 49.58 \mathrm{~L} 17.06 \mathrm{H} 27.69 \mathrm{~L} 25.03 \mathrm{H} 18.8 \mathrm{~L}$ $31.87 \mathrm{H} 9.84 \mathrm{~L} 150.55 \mathrm{H} \quad 6.26 \mathrm{~L} \quad 23.86 \mathrm{H} \quad 32.29 \mathrm{~L} 11.67 \mathrm{H}$ $215.82 \mathrm{~L} 15.27 \mathrm{H} 26.04 \mathrm{~L} 117.25 \mathrm{H} 15.75 \mathrm{~L} 17.37 \mathrm{H} 33.9 \mathrm{~L}$ $5.67 \mathrm{H} 488.99 \mathrm{~L} 6.05 \mathrm{H} 25.1 \mathrm{~L} \quad 12.21 \mathrm{H} \quad 14.93 \mathrm{~L} \quad 110.92 \mathrm{H}$ 26.71L $13.4 \mathrm{H} 198.49 \mathrm{~L} 11.95 \mathrm{H} 22.79 \mathrm{~L} 107.25 \mathrm{H} 25.24 \mathrm{~L}$ $15.31 \mathrm{H} \quad 212.5 \mathrm{~L} \quad 9.62 \mathrm{H} \quad 19.36 \mathrm{~L} \quad 10.88 \mathrm{H} \quad 12.95 \mathrm{~L} \quad 112.5 \mathrm{H}$

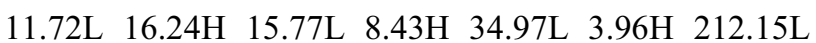
40.78L $7.27 \mathrm{H} \quad 36.94 \mathrm{~L} 12.97 \mathrm{H} \quad 20.45 \mathrm{~L} \quad 18.94 \mathrm{H} \quad 15.28 \mathrm{~L}$ $24.33 \mathrm{H} \quad 13.48 \mathrm{~L} \quad 22.01 \mathrm{H} \quad 19.22 \mathrm{~L} \quad 12.64 \mathrm{H} \quad 38.5 \mathrm{~L} \quad 7.59 \mathrm{H}$ $225.9 \mathrm{~L} 6.98 \mathrm{H} 39.31 \mathrm{~L} 11.67 \mathrm{H} 45.42 \mathrm{~L} 12.05 \mathrm{H} 106.47 \mathrm{~L} \mathrm{~A}$

This thin film consisted of 91 layers with total thickness of $4551.6 \mathrm{~nm}$. films.

Figure 2 shows the transmittance for the two thin

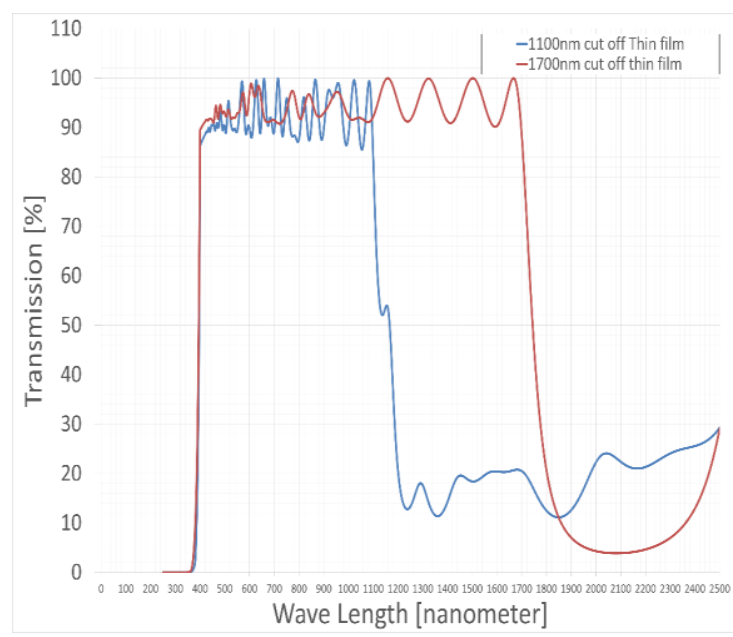

Figure 2. Thin film transmittance curve as a function of wavelength.

\section{Heat Transfer module of CPV module}

Heat transfer simulation for the CPV module was carried out using COMSOL Multiphysics. Figure 3 shows the geometry model developed for the calculating of heat transfer in the CPV module. The receiver consisted of homogenizer, III V solar cell, a solder, a copper electrode, insulation materials and aluminium stage which was mounted on the aluminium chassis.

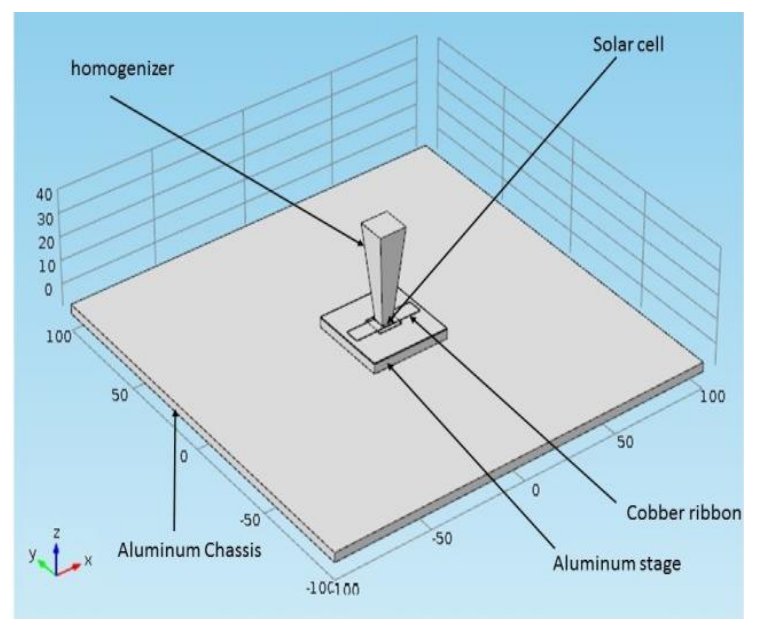

Figure 3. Simple geometry module for the heat transfer simulation.

I.Antón et al. [7] reported that the cell temperature $\left(\mathrm{T}_{\text {cell }}\right)$ could be related to the module temperature (temperature at the back surface of CPV module) through:

$$
T_{\text {cell }}=T_{\text {module }}+R_{\text {th_cell_heatsink }} \times P,
$$


where $\mathrm{T}_{\text {module }}(\mathrm{K})$ is module temperature at back surface, $\mathrm{R}_{\text {th_cell_heatsink }}(\mathrm{K} / \mathrm{W})$ is thermal resistance between the cell and the back chassis or heat sink core, and $\mathrm{P}(\mathrm{W})$ is the heat power, respectively. The heat Power was related to the direct normal irradiance (DNI) through:

$$
P=D N I \times A_{\text {cell }} \times C \times \eta_{o p} \times(1-\eta)
$$

where $A_{\text {cell }}$ is the solar cell area, (C) is the concentration ratio, $\eta_{\text {op }}$ is the optical efficiency, and $\eta$ is the electrical efficiency. $A_{\text {cell }}$ was fixed to $5.5 \times 5.5 \mathrm{~mm}^{2}$. The initial temperature was $300 \mathrm{~K}$.

\section{Results and discussion}
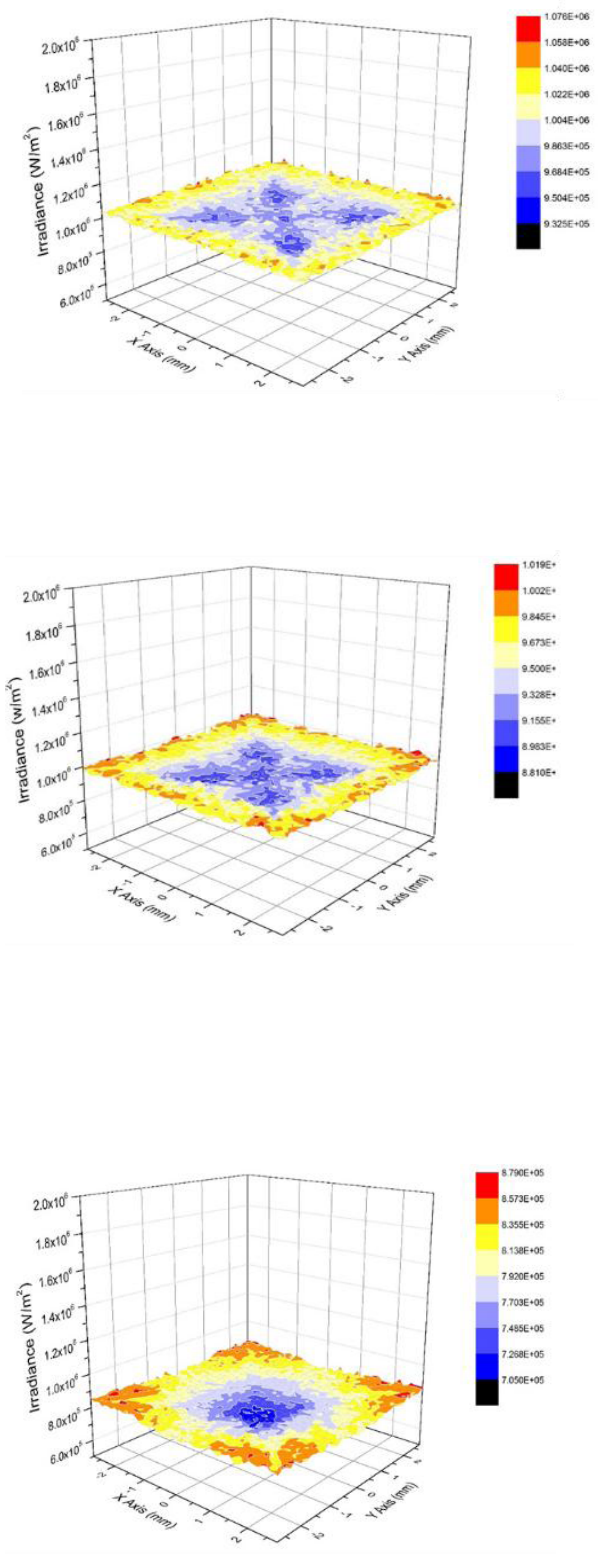

Figure 4. Calculated irradiance distribution on the solar cell.
Using ray-trace simulation we analysed the irradiance distribution on the solar cell for three cases; a)No thin film on the homogenizer face, b) $1700 \mathrm{~nm}$ cutoff wavelength thin film, and c) $1100 \mathrm{~nm}$ cutoff wavelength thin Film. Figure 4 shows the irradiance distribution on the solar cell for these three cases. The results showed good irradiance uniformity due to the use of homogenizer in all three cases.

Heat transfer simulation for the CPV module was carried out using COMSOL Multiphysics. The receiver consisted of homogenizer, III-V solar cell, a solder, a copper electrode, insulation materials and aluminium stage mounted on the aluminium chassis. Figure 5 shows the temperature distribution on the solar cell for each case. The results of thermal simulation for the three cases showed that the highest temperature was observed for the case of no thin film $\left(118.7^{\circ} \mathrm{C}\right)$, while the temperature dropped to $114.5^{\circ} \mathrm{C}$ in the case of $1700 \mathrm{~nm}$ cutoff wavelength thin film with total drop of about $4^{\circ} \mathrm{C}$ in temperature.

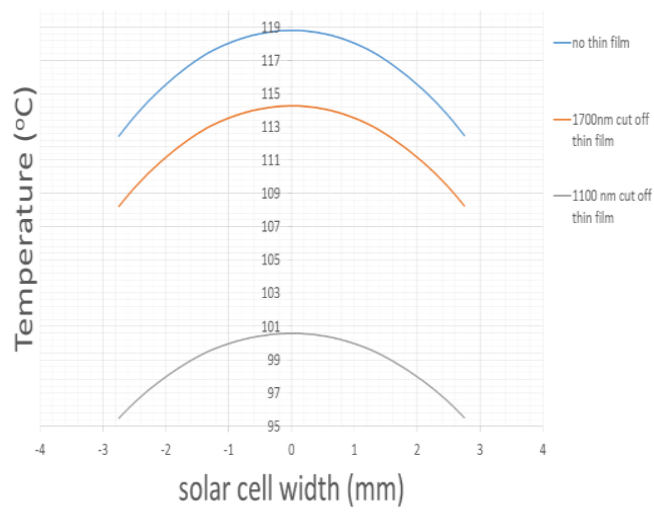

Figure 5. Temperature gradient on the solar cell surface.

The best thermal performance was achieved by the $1100 \mathrm{~nm}$ cutoff wavelength thin film case where the temperature decreased by $18.2^{\circ} \mathrm{C}$ to $100.5^{\circ} \mathrm{C}$. The use of the thin film will have great effect on the solar cell performances.

\section{Conclusion}

Optical and thermal simulation have been conducted to an optical system with two types of multi junction solar cell and thin film that allows only the spectrum in which the solar cell has the highest response to pass through. Results showed great increase in the thermal performance of the $\mathrm{InGaP} / \mathrm{GaAs} / \mathrm{InGaAs}$ triple junction with decrease in total temperature by about $18.2 \mathrm{oC}$ from the no thin film case. The use of the thin film will have great effect on the solar cell performances. 


\section{References:}

1. K. Araki, M. Yamaguchi, Sol. Energy Mater. Sol. Cells 75, 467 (2003).

2. M. Bosi, C. Pelosi, Prog. Photovolt: Res. Appl. 15, 51 (2007).

3. W. Guter, J. Schöne, S. P. Philipps, M. Steiner, G. Siefer, A. Wekkeli, E.Welser, E. Oliva, A. W. Bett, and F. Dimroth, Appl. Phys. Lett. 94, 223504 (2009).

4. K. Sasaki, T. Agui, K. Nakaido, N. Takahashi, R. Onitsuka, and T. Takamoto, AIP Conf. Proc. 1556, 22 (2013).
5. A.V. Tikhonravov, M.K. Trubetskov, and G.W. DeBell, Applied Optics. 35, 5493 (1996).

6. A.V. Tikhonravov, M.K. Trubetskov, and G.W. DeBell, Applied Optics. 46, Issue 5, 704 (2007).

7. I. Anton, M. Martinez, F. Rubio, R. Nunez, R. Herrero, C. Dominguez, M. Victoria, S. Askins, and G. Sala, AIP Conference Proceedings (8th International Conference on Concentrating Photovoltaic Systems), 1477, 331 (2012). 